\title{
Corneal and conjunctival calcification in chronic renal failure
}

\author{
R. PORTER AND A. L. GROMBIE \\ University Department of Ophthalmology, Royal Victoria Infirmary, Newcastle upon Tyne, $\mathcal{N} E_{\mathrm{I}}{ }_{4} L P$
}

The deposition of calcium salts in the cornea and conjunctiva of patients with hypercalcaemia has been noted for some time, especially in the conditions of hyperparathyroidism (Cogan, Albright, and Bartter, 1948; Walsh and Murray, I953), sarcoidosis (Cogan and others, I948; Walsh and Murray, I953; Crick, Hoyle, and Smellie, I96r ; Cogan and Henneman, 1957), and vitamin D intoxication (Walsh and Murray, 1953; Howard and Meyer, I948; Leira, I954; Smith, 1957). More recently Berlyne and Shaw (1967, 1968) reported similar deposits in patients with acute and chronic renal failure in whom by contrast there was hypocalcaemia and marked hyperphosphataemia. They also found that the calcium and inorganic phosphate product was usually greater than 70 in these patients, and further suggested that these deposits were responsible for the red eye of renal failure. Other workers have confirmed the presence of these deposits in uraemic patients but have questioned the aetiology of the red eye (Harris, Cohn, Toyofuku, Lonergan, and Galin, 197I; Caldeira, Sabbaga, and Ianhez, 1970).

The purpose of this paper was to assess ocular calcium deposits in a moderately large group of patients with chronic renal failure, and to find if there is any correlation between these deposits, the red eye of renal failure, reduced tear production, and the bony rarefaction which often occurs in such patients. Finally, the effect of regular haemodialysis and renal transplantation on such deposits was observed over periods of from $\mathrm{I}$ to 4 years.

\section{Patients and methods}

$3^{8}$ patients on haemodialysis were examined over a period of from $\mathrm{I}$ to 4 years. There were seventeen male and twenty-one female patients, the average age in both groups being 33 years. Of those who received a donor kidney during this period, eleven have been observed to date. An additional group of eight patients who were seen for the first time after renal transplantation was also observed. All patients had a full ocular examination and in particular the calcium deposits were examined and graded, depending on their position and extent (Figure, overleaf). Tear secretion was estimated by Schirmer's method (Duke-Elder, 1965), and any patient with a red eye was further investigated to ensure that no other pathology was present. $X$-ray reports of routine skeletal surveys were collected and attempts were made to correlate the extent of the bony changes found with the degree of corneal and conjunctival calcification. Finally, levels of serum calcium and inorganic phosphate were measured in each patient.

\section{Results}

All the $3^{8}$ patients had calcium deposits of some degree when first examined. As might be expected, these tended to increase with the duration of the renal failure (Table I, overleaf).

These deposits were confined to the areas of the cornea and conjunctiva exposed at the palpebral aperture, the greatest concentration always being at the limbus and centred on 


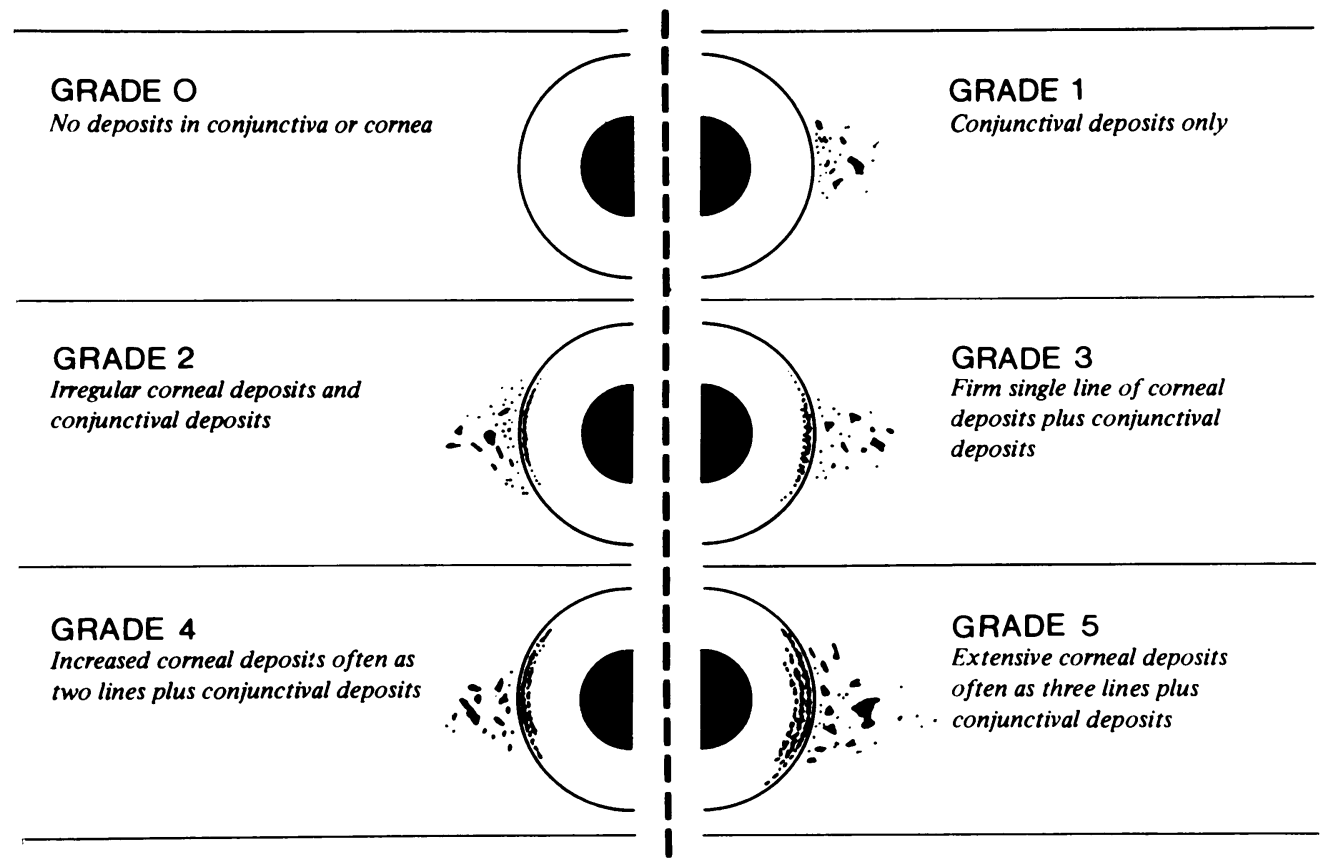

FIGURE System of grading corneal and conjunctival calcium deposits

Table I Number of patients in each grade when first seen

\begin{tabular}{|c|c|c|c|c|c|c|}
\hline Grade of calcification & o & $\mathbf{I}$ & 2 & 3 & 4 & 5 \\
\hline No of. patients & o & 4 & I 7 & I3 & 4 & o \\
\hline $\begin{array}{l}\text { Average duration of } \\
\text { renal failure }(\mathrm{yrs})\end{array}$ & o & $0 \cdot 6$ & $1 \cdot 4$ & $1 \cdot 7$ & $2 \cdot 7$ & - \\
\hline
\end{tabular}

the 9 to 3 o'clock meridian. The conjunctival deposits were initially found in isolated subepithelial crystals, but later flatter smoother plaques appeared. The corneal deposits progressed in a peculiarly characteristic fashion. The initial deposit was a faint line of crystals just inside the limbus and concentric to it with its centre on the 9 to 3 o'clock meridian (Grade 2-3). It was usually connected to the limbus by even fainter centrallyplaced deposits. As the corneal calcification progressed, a second line often appeared within and concentric to the first and joined to it centrally by finer deposits but distinctly independent of it at the extremities (Grade 4). In a small number of patients with extensive corneal deposits, a third line became visible joined at its centre as before. This last (Grade 5) was not found in any of the patients when first seen, but developed during the period of observation in a number of those who had been on haemodialysis for some years.

In this series only four patients had the red eye of renal failure and although they had numerous minute nodules in the conjunctiva due to subepithelial calcium deposits which looked understandable causes of ocular irritation, the deposits did not differ from those in a number of the other $3^{8}$ patients. Similarly, all four patients had abnormally low 
levels of tear production as measured by Schirmer's test (Table II), and three were particularly deficient in this respect. However, despite this more significant correlation, the other four patients in column one of Table II had equivalent calcium deposits.

Table II Results of Schirmer's test for tear production.

The "red eye" patients in each group are in brackets

\begin{tabular}{lllll}
\hline Schirmer's test (mm.) & $\frac{0-5}{7(3)}$ & $\frac{5^{-15}}{12(1)}$ & $\frac{15}{19}$ \\
\hline Number of patients & $\frac{7(3)}{2}$ & & &
\end{tabular}

Table III Serum calcium, phosphate, and calcium phosphate product in the patients on regular haemodialysis. Final column shows fate of calcium deposits during the period of observation

\begin{tabular}{|c|c|c|c|c|c|c|c|c|c|}
\hline \multirow{2}{*}{ Data } & \multicolumn{2}{|c|}{$\begin{array}{l}\text { Serum calcium } \\
(\mathrm{mg} . / \mathrm{I} 00 \mathrm{ml} .)\end{array}$} & \multicolumn{2}{|c|}{$\begin{array}{l}\text { Serum phosphate } \\
(\mathrm{mg} . / \mathrm{I} 00 \mathrm{ml} .)\end{array}$} & \multicolumn{2}{|c|}{$\mathrm{Ca} \times \mathrm{PO}_{4}$} & \multicolumn{3}{|c|}{ Calcium deposits } \\
\hline & Low & Normal & High & Normal & $<70$ & $>70$ & Reduced & Unchanged & Increased \\
\hline $\begin{array}{l}\text { No. of } \\
\text { patients }\end{array}$ & 8 & 30 & 34 & 4 & 13 & 25 & I & 5 & $3^{2}$ \\
\hline
\end{tabular}

In the majority of these patients the corneal and conjunctival grading increased with time despite treatment with regular haemodialysis and, as other workers have reported, the majority also had a raised serum inorganic phosphate and a calcium-phosphate product greater than 70 (Table III). The eleven patients who subsequently received a donor kidney, if considered separately, show a similar trend (Table IV).

Table IV Similar data to that in Table III for eleven patients before renal transplantation

\begin{tabular}{|c|c|c|c|c|c|c|c|c|c|}
\hline \multirow[t]{2}{*}{ Data } & \multicolumn{2}{|c|}{$\begin{array}{l}\text { Serum calcium } \\
(\mathrm{mg} . / 100 \mathrm{ml} .)\end{array}$} & \multicolumn{2}{|c|}{$\begin{array}{l}\text { Serum phosphate } \\
\text { (mg./100 ml.) }\end{array}$} & \multicolumn{2}{|c|}{$\mathrm{Ca} \times \mathrm{PO}_{4}$} & \multicolumn{3}{|c|}{ Calcium deposits } \\
\hline & Low & Normal & High & Normal & $<70$ & $>70$ & Reduced & Unchanged & Increased \\
\hline $\begin{array}{l}\text { No. of } \\
\text { patients }\end{array}$ & 2 & 9 & 10 & I & 4 & 7 & o & 2 & 9 \\
\hline
\end{tabular}

No correlation was found between the degree of calcium deposition and the amount of bone resorption. Some patients with marked degrees of corneal calcification had no bony changes of note.

Finally, in the group of patients who subsequently received a donor kidney, the majority showed a reduction in the amount of corneal and conjunctival calcification (Table V).

Table $\mathbf{V}$ Findings in the same eleven patients from 6 months to 3 years after renal transplantation (cf. Table IV)

\begin{tabular}{|c|c|c|c|c|c|c|c|c|c|}
\hline \multirow{2}{*}{ Data } & \multicolumn{2}{|c|}{$\begin{array}{l}\text { Serum calcium } \\
(\mathrm{mg} . / \mathrm{1} \text { oo } \mathrm{ml} .)\end{array}$} & \multicolumn{2}{|c|}{$\begin{array}{l}\text { Serum phosphate } \\
\text { (mg./100 ml.) }\end{array}$} & \multicolumn{2}{|c|}{$\mathrm{Ca} \times \mathrm{PO}_{4}$} & \multicolumn{3}{|c|}{ Calcium deposits } \\
\hline & Abnormal & Normal & Low & Normal & $<70$ & $>70$ & Reduced & Unchanged & Increased \\
\hline $\begin{array}{l}\text { No. of } \\
\text { patients }\end{array}$ & 0 & II & 6 & 5 & I I & o & 7 & 4 & o \\
\hline
\end{tabular}


In one patient the deposits disappeared altogether. A further smaller group of eight patients, who were seen for the first time after renal transplantation, confirmed this trend (Table VI).

Table VI Data on additional group of eight patients seen for the first time after renal transplantation

\begin{tabular}{|c|c|c|c|c|c|c|c|c|c|}
\hline \multirow{2}{*}{ Data } & \multicolumn{2}{|c|}{$\begin{array}{l}\text { Serum calcium } \\
(\mathrm{mg} . / \mathrm{100} \mathrm{ml} .)\end{array}$} & \multicolumn{2}{|c|}{$\begin{array}{l}\text { Serum phosphate } \\
(\mathrm{mg} . / \mathrm{100} \mathrm{ml} .)\end{array}$} & \multicolumn{2}{|c|}{$\mathrm{Ca} \times \mathrm{PO}_{4}$} & \multicolumn{3}{|c|}{ Calcium deposits } \\
\hline & Abnormal & Normal & Low & Normal & $<70$ & $>70$ & Reduced & Unchanged & Increased \\
\hline $\begin{array}{l}\text { No. of } \\
\text { patients }\end{array}$ & I & 7 & I & 7 & 8 & o & 4 & 4 & o \\
\hline
\end{tabular}

\section{Discussion}

This series confirms the previous reports (Cogan and others, 1948; Berlyne and Shaw, 1967; Berlyne, 1968; Harris and others, I971; Caldeira and others, 1970); of the common occurrence of calcium deposits in both the cornea and conjunctiva of patients with chronic renal failure. Their method of formation is unknown, but the most satisfactory theory is that $\mathrm{CO}_{2}$ is lost from the cornea and conjunctiva exposed by the palpebral aperture with a resultant rise in $\mathrm{pH}$, so that, in the presence of a high serum calcium-phosphate product, calcium salts are deposited. They are situated subepithelially (Berlyne, I968) and have been shown by $x$-ray diffraction to be calcium hydroxyapatite (Berkow, Fine and Zimmerman, I968). It has been suggested (Berlyne and Shaw, 1967) that hyperphosphataemia and a high serum calcium-phosphate product were a necessary environment for such deposits, but other factors must be at work, as it is well known that similar deposits occur in patients with conditions such as hyperparathyroidism and vitamin $\mathrm{D}$ overdosage with their associated hypercalcaemia and occasional hypophosphataemia. Berkow and others (1968) suggested that parahormone may be responsible for the laying down of these calcium deposits in these conditions. The curious and hitherto undescribed banding of the corneal deposits is unexplained. It may be due to slow fluctuations in the serum levels of calcium and phosphate which periodically provide an environment conducive to the crystallization of the calcium salts.

Four patients in this series had red irritable eyes with no signs of an associated infection. All four had marked conjunctival deposits but these were in no way different from similar deposits in a number of the other patients. More significant were the abnormally low levels of tear production in these four patients and indeed none of the seventeen patients who had normal tear production complained of red eyes. It seems probable, therefore, that certain conjunctival deposits exposed by an inadequate tear film are responsible for the irritable red eyes, but against this theory are the four patients with a similar combination of dry eyes and extensive conjunctival deposits who at no time had signs or symptoms of a red eye.

Previous reports (Harris and others, 1971) suggested that these corneal deposits were unaffected by treatment with regular haemodialysis. This series confirms this and, indeed, in the majority of the patients, the corneal and conjunctival deposits increased in extent during the period of regular haemodialysis. However, as was shown by Caldeira and others (1970) in the report of one patient, the deposits will regress in patients who have received a donor kidney. This occurred in the majority of the patients in this series who had renal transplants and none of them showed any further progression of the deposits. 


\section{Summary}

The characteristic deposits of calcium salts in the cornea and conjunctiva of patients with chronic renal failure are described. The possible association between these deposits and reduced tear production in the aetiology of the red eye in renal failure are discussed. The deposits increased in extent in patients treated with regular haemodialysis and markedly regressed in patients receiving transplanted kidneys.

We are grateful to Prof. D. N. S. Kerr for permission to examine patients under his care, and to Miss D. Mustart for preparing Table I.

\section{References}

Berkow, J. W., fine, B. S., and zimmerman, L. E. (1968) Amer. F. Ophthal., 66, 8 I 2 (1968) Ibid., 2, 366

BERLYNE, G. M., and SHAW, A. E. (1967) Lancet, 1,4

Caldeira, J. A. F., SABAga, E., and ianhez, L. E. (1970) Brit. J. Ophthal., 54, 399

COGAN, D. G., Albright, F., and BARTter, F. c. (1948) Arch. Ophthal. (Chicago), 40, 624

and henneman, P. H. (1957) New Engl. F. Med., 257, $45^{\mathrm{I}}$

GRICK, R. P., HOYLE, C., and SMELlie, H. (196I) Brit. F. Ophthal., 45, 46 I

DUKE-ELDER, s. (1965) "System of Ophthalmology", vol. 8, pt. I, "Diseases of the Outer Eye", p. 132. Kimpton, London

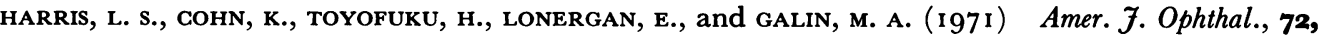
I 30

HOWARD, J. E., and MEYER, R. J. (1948) $\quad$ F. clin. Endocr., 8, 895

LEIRA, H. (1954) Acta ophthal. (Kbh.), 32, 605

SMrTh, J. LAWTON (1957) Amer. F. Ophthal., 43, 575

WALSH, F. B., and MURRAY, R. G. (1953) Ibid., 36, I657 